\title{
Analisis Potensi Sumber Daya Manusia Untuk Pengembangan Usaha Peternakan Sapi Potong Di Kabupaten Pesisir Selatan
}

\section{Human Resourses Analisys for Development of Beef Cattle Farming in Pesisir Selatan Regency}

\author{
A. Suresti, R. Wati, dan I. Indrayani \\ Fakultas Peternakan, Universitas Andalas Padang \\ e-mail: rahmi.unand@gmail.com
}

(Diterima: 12 November 2012; Disetujui: 4 Februari 2013)

\begin{abstract}
This study aims to: (1). determined the potential of human resources (Breeders) for the development of beef cattle; (2). calculating employment opportunities based on the elasticity of employment. This research was conducted in Pesisir Selatan Regency, West Sumatra Province. The data was collected using a survey method. The population of this study were 99 RTP. The sampling method used simple random sampling technique. Analysis of the data used the qualitative and quantitative analysis deskriptif. The results showed that farmers in particular human resources in this area was not sufficient to develop their business in a better direction, it was seen from education and working hours for the beef cattle business in which $62.9 \%$ of farmers did not finish his formal education as well as technical knowledge still low despite having an average breeding experience of over 10 years. Time that the need to maintain a single head of cattle per day was 0.75 hours / cow / day or equal to 0.0938 HOK. Employment elasticity of 0.24. That was, if the Pesisir Selatan Regency GDP increased by one percent, there will be job creation livestock sector by 0.24 percent.
\end{abstract}

Key words: Analysis of Potential, the elasticity of employment, development of Beef Cattle, Pesisir Selatan Regency, West Sumatra.

\section{PENDAHULUAN}

Ditjen Peternakan (2003) melaporkan bahwa populasi sapi potong di Indonesia menurun dalam lima tahun terakhir, dengan ratarata penurunan $1,08 \%$ per tahun, sementara itu jumlah pemotongan selalu meningkat sebesar $0,61 \%$ tiap tahun. Demikian juga halnya dengan Sumatera Barat, rata-rata peningkatan populasi sapi potong sebesar $2,05 \%$ pertahun, sedangkan jumlah pemotongan meningkat sebesar 2,50\% per tahun (BPS Sumatera Barat 2005). Untuk mengatasi kesenjangan ini diperlukan import sapi potong dalam jumlah yang cukup besar, pada tahun 2002 impor sapi bakalan mencapai 400.000 ekor, dan daging setara dengan 120.000 ekor sapi potong (Ditjen Peternakan, 2003). Volume impor yang cukup besar ini, perlu dicermati dan diantisipasi agar ketergantungan dari impor bisa berkurang.
Saat ini usaha dari peternakan untuk menghasilkan sapi bakalan dalam negeri (cowcalf operation) 99\% dilakukan oleh peternak rakyat. Usaha ini tetap bertahan karena ternak sapi dipelihara dalam suatu sistem yang terintegrasi dengan usaha tani lainnya. Dengan adanya sistem integrasi tanaman ternak yang telah dilakukan oleh petani di pedesaan akan mampu meningkatkan efisiensi dan daya saing sekaligus meningkatkan pendapatan petani (Dwiyanto, 2002).

Persoalan mengenai sumber daya manusia menjadi masalah yang serius bagi sub sektor peternakan. Fakta menunjukkan bahwa kapasitas sumber daya manusia dalam berusaha tani sangat rendah sehingga menimbulkan dampak yang jelas tidak menguntungkan bagi sektor atau sub sektor yang memiliki posisi lemah termasuk sub sektor peternakan. Penggunaan tenaga kerja yang professional berarti langsung berkaitan dengan pendidikan, 
ketrampilan serta motivasi berwirausaha untuk pengembangan usaha peternakan sapi potong. Ini terjadi sebagai konsekuensi dari persaingan dengan industri dan lain-lain. Sehubungan dengan hal tersebut, maka diperlukan suatu pengalokasian sumberdaya yang tepat untuk melakukan pengembangan sehingga diperlukan persiapan suatu wilayah yang berpotensi dijadikan sebagai wilayah pengembangan usaha peternakan sapi potong. Sumberdaya manusia pertanian yang dibutuhkan untuk masa depan adalah SDM yang menguasai ilmu pengetahuan dan teknologi pertanian, memiliki jiwa entrepreneurship, serta siap menghadapi kompetisi bisnis, baik pada tataran lokal, nasional, regional, maupun global (Salikin, 2003). Di lain pihak, Satria (2003) yang dikutip oleh Salikin (2003) menyatakan bahwa yang dibutuhkan sekarang dan masa depan adalah sosok petani berbudaya modern, dengan ciri-ciri antara lain memiliki kemampuan manajemen modern, mampu bekerjasama, terspesialisasi, dan mampu bekerja secara produktif dan efisien. Dengan kata lain yaitu sosok petani yang berbudaya industri sangat dibutuhkan untuk masa kini dan masa depan. Berdasarkan latar belakang tersebut, dalam upaya pemberdayaan SDM peternakan untuk menuju usaha ternak sapi potong yang berdaya-saing, secara mendasar diperlukan calon-calon sumber daya manusia yang profesional dan berbudaya industri.

Kabupaten Pesisir Selatan merupakan salah satu sentra pengembangan sapi potong di Sumatera Barat. Kabupaten Pesisir Selatan sebagai alternatif untuk pengembangan usaha ternak sapi potong (sapi pesisir) didasarkan pada beberapa alasan penting diantaranya adalah adanya sumberdaya alam dan sumberdaya manusia yang dimiliki kabupaten Pesisir Selatan, keadaan lingkungan yang mendukung, tersedianya sarana dan prasarana yang memadai serta adanya fasilitas pendukung. Melihat kondisi ini maka Kabupaten Pesisir Selatan masih mempunyai peluang untuk pengembangan peternakan. Berdasarkan kondisi di atas maka tujuan dari penelitian ini adalah mengetahui Potensi sumberdaya manusia untuk pengembangan usaha sapi potong, dan menghitung peluang penyerapan tenaga kerja berdasarkan elastisitas kesempatan kerja.

\section{METODE}

Penelitian ini dilaksanakan di Kabupaten Pesisir Selatan Propinsi Sumatera Barat. Pemilihan daerah penelitian dilakukan secara Purposive (sengaja) dengan pertimbangan, bahwa di Kabupaten Pesisir Selatan sektor pertanian merupakan ciri dominan perekonomian. Kondisi geografi dan sumberdaya alamnya mendukung kegiatan sektor ini, dalam menghadapi pelaksanaan otonomi daerah kegiatan sektor pertanian merupakan salah satu sektor yang diprioritaskan untuk meningkatkan pendapatan masyarakat di pedesaaan.

Pengumpulan data dilakukan dengan menggunakan metode survey. Para responden akan diberikan beberapa pertanyaan dalam bentuk daftar pertanyaan (kuesioner) yang nantinya akan dipandu oleh tenaga pencacah (surveyor). Data yang akan digunakan dalam penelitian ini adalah data primer dan data sekunder sesuai dengan kebutuhan penelitian. Data primer diperoleh dari hasil wawancara langsung dengan peternak yang ada di lokasi penelitian.

Populasi dari penelitian ini sebanyak 99 RTP. Metode pengambilan sampel dengan menggunakan teknik simple random sampling. Analisa data yang digunakan adalah Analisis deskriptif kualitatif digunakan untuk menganalisa tujuan pertama. Data yang digunakan digunakan untuk menggambarkan kondisi sumber daya manusia (peternak) adalah tingkat pendidikan, umur, lama beternak, curahan waktu untuk usaha sapi potong.

Untuk tujuan kedua dianalis secara kuantitatif dengan penghitungan elastisitas kesempatan kerja. Secara makro, elastisitas kesempatan kerja (employment elasticity) seringkali diartikan sebagai perbandingan perubahan struktur dan laju pertumbuhan kesempatan kerja dengan perubahan struktur dan laju pertumbuhasn ekonomi, di mana perubahan struktur dan laju pertumbuhan ekonomi akan mempengaruhi besarnya struktur dan laju per- 
tumbuhan kesempatan kerja, seperti rumus di bawah ini:

$$
E i \quad=R L i / R Y i
$$

Dimana:

$$
\begin{aligned}
E i= & \text { Elastisitas kesempatan Kerja sektor } \\
& \text { I (Peternakan) } \\
R L i= & \text { Laju Pertumbuhan Kesempatan Kerja } \\
& \text { Sektor I pertahun } \\
R Y i= & \text { Laju pertumbuhan Nilai tambah } \\
& \text { sektor I pertahun. }
\end{aligned}
$$

Apabila laju pertumbuhan ekonomi sektor I (RYi) pertahun diketahui, maka dapat ditentukan besarnya kesempatan kerja sektor i pada tahun $t$ dimasa yang akan datang dengan menggunakan formula sebagai berikut :

$$
\text { Lit }=\operatorname{Lio}(1+R I i)^{t}
$$

\section{HASIL DAN PEMBAHASAN}

\section{Kondisi Umum Sumber Daya Manusia di Kabupaten Pesisir Selatan}

Jumlah penduduk Kabupaten Pesisir Selatan tahun 2007 tercatat sebanyak 433.181 jiwa, terdiri dari 213.462 laki-laki, 219.719 perempuan, jumlah rumah tangga sebanyak 97.977, ratio jenis kelamin sebesar 97,15\% artinya jumlah penduduk perempuan lebih banyak dibandingkan dengan penduduk lakilaki. Jumlah ini tersebar pada 11 kecamatan di Kabupaten Peisisir Selatan dengan luas daerah $5.749,89 \mathrm{Km}^{2}$. Jumlah penduduk menurut kelompok umur dapat dilihat pada Tabel 1.

Ratio jenis kelamin (sex ratio) pada tahun 2007 lebih tinggi jika dibandingkan dengan tahun 2006, yakni dari 97,03 menjadi 97,15 pada tahun 2007, artinya dalam 100 orang penduduk perempuan terdapat 97,15 orang penduduk laki-laki. Kepadatan penduduk Kabupaten Pesisir Selatan pada tahun 2007 tercatat sekitar 75 jiwa per kilometer persegi naik 1 jiwa dibandingkan dengan keadaan tahun 2006.

Angkatan kerja di Pesisir Selatan pada tahun 2007 tercatat sebanyak 184.916 orang. Bila dilihat dari angkatan kerja yang ada, hanya $163.282(88,3 \%)$ saja yang bekerja atau memiliki pekerjaan, sedangkan sisanya sebanyak $50.638(11,7 \%)$ adalah mereka yang sedang mencari pekerjaan atau menganggur (BPS Kabupaten Pesisir Selatan, 2007). Terdapat berbagai lapangan kerja seperti terlihat pada Tabel 2 .

Tabel 1. Jumlah Penduduk Menurut Kelompok Umur

\begin{tabular}{ccc}
\hline No. & Kelompok Umur (th) & Jumlah (jiwa) \\
\hline 1 & $0-4$ & 44.285 \\
2 & $5-9$ & 44.848 \\
3 & $10-14$ & 45.723 \\
4 & $15-19$ & 45.107 \\
5 & $20-24$ & 43.283 \\
6 & $25-29$ & 40.063 \\
7 & $30-34$ & 34.632 \\
8 & $35-39$ & 28.140 \\
9 & $40-44$ & 23.372 \\
10 & $45-49$ & 20.775 \\
11 & $50-54$ & 19.910 \\
12 & $55-59$ & 14.372 \\
13 & $60-64$ & 12.937 \\
14 & $65-69$ & 9.365 \\
15 & $70+$ & 6.369 \\
\hline
\end{tabular}

Sumber : BPS Kabupaten Pesisir Selatan (2007) 
Tabel 2. Sebaran Penduduk Yang Bekerja Berdasarkan Lapangan Usaha Utama

\begin{tabular}{clcc}
\hline No. & \multicolumn{1}{c}{ Lapangan Usaha Utama } & Jumlah (jiwa) & Persentase (\%) \\
\hline 1 & Pertanian & 95.872 & 58,72 \\
2 & Industri Pengolahan & 6.780 & 4,15 \\
3 & Perdagangan, Rumah Makan, Dan Hotel & 27.085 & 16,59 \\
4 & Jasa Kemasyarakatan & 14.957 & 9,16 \\
5 & Lainnya & 18.588 & 11,38 \\
\hline \multicolumn{2}{c}{ Total } & 163.282 & 100 \\
\hline
\end{tabular}

Sumber : BPS Kabupaten Pesisir Selatan (2007)

Tabel 3. Data Angkatan Kerja Kabupaten Pesisir Selatan Tahun 2005 - 2009

\begin{tabular}{lrrrrr}
\hline \multicolumn{1}{c}{ Keterangan } & \multicolumn{1}{c}{2005} & 2006 & \multicolumn{1}{c}{2007} & \multicolumn{1}{c}{2008} & 2009 \\
\hline ANGKATAN KERJA & 198,364 & 197,484 & 184,916 & 176,690 & 167,304 \\
- Bekerja & 154,012 & 146,846 & 163,282 & 160,929 & 161,054 \\
- Pencari Kerja Terdaftar & 44,352 & 50,638 & 21,634 & 15,761 & 6,250 \\
BUKAN ANGKATAN KERJA & 225,245 & 230,664 & 248,265 & 265,567 & 281,184 \\
- Sekolah & 70,233 & 66,038 & 25,459 & 24,670 & 27,877 \\
- Pendd. Yang berusia < 15 thn dan > 60 thn & 155,812 & 164,626 & 222,806 & 240,897 & 291,023 \\
\hline Jumlah Penduduk & 423,609 & 428,148 & 433,181 & 442,257 & 448,488 \\
\hline
\end{tabular}

Sumber : Dinas Sosial, Tenaga Kerja dan Transmigrasi Kab. Pesisir Selatan,2009

\section{Kondisi Tenaga Kerja}

Masalah ketenagakerjaan merupakan salah satu prioritas pembangunan bidang ekonomi yang keterkaitannya sangat kuat dengan sektor lainnya. Menyusun kebijakan sektor ketenagakerjaan adalah identik dengan meningkatkan kualitas sumber daya manusia (SDM) yang notabene dibutuhkan oleh sektor pembangunan lainnya. Untuk meningkatkan kemampuan tenaga kerja, maka pemerintah harus bisa mendorong atau memberikan fasilitas. Dengan dibuatnya fasilitas Balai Latihan kerja maupun pelatihan - pelatihan maka akan meningkatkan daya saing kemampuan tenaga kerja. Berikut ini ditampilkan data proyeksi angkatan kerja yang ada di Kabupaten Pesisir Selatan.

Tabel 3 menunjukkan bahwa orang yang bekerja pada tahun 2005 adalah sebanyak 154.012 orang dan meningkat pada tahun 2009 menjadi 161.054 orang, naik rata-rata pertahun sebesar $0,95 \%$. Sedangkan pencari kerja yang terdaftar di Dinas Sosial, Tenaga Kerja dan Transmigrasi Kabupaten Pesisir Selatan mengalami penurunan dari tahun 2005 ke tahun 2009. Pada tahun 2005 jumlah pencari kerja sebanyak 44.352 orang dan menurun pada tahun 2009 menjadi 6.250 orang. Hal ini menunjukkan bahwa masyarakat Kabupaten Pesisir Selatan cukup baik dalam penanggulangan masalah pengangguran. Dengan naiknya jumlah yang bekerja dan semakin sedikitnya jumlah pencari kerja diharapkan kesejahteraan masyarakat Pesisir Selatan semakin lebih baik lagi.

Jika kita lihat Rasio lulusan S1/S2/S3 adalah jumlah lulusan S1/S2/S3 per 10.000 penduduk. Kualitas tenaga kerja di suatu wilayah sangat ditentukan oleh tingkat pendidikan. Artinya semakin tinggi tingkat pendidikan yang ditamatkan penduduk suatu wilayah maka semakin baik kualitas tenaga kerjanya. Sedangkan Rasio ketergantungan adalah perbandingan jumlah penduduk usia $<15$ tahun dan $>64$ tahun terhadap jumlah penduduk usia 15-64 tahun. Rasio ketergantungan digunakan untuk mengukur besarnya beban yang harus ditanggung oleh setiap penduduk berusia produktif terhadap penduduk yang tidak produktif. (Dinas peternakan Kab.Pesisir Selatan, 2009) 


\section{Kondisi Peternakan Sapi Potong}

Populasi ternak sapi potong di Kabupaten Pesisir Selatan tahun 2003-2007 mengalami peningkatan, dapat dilihat pada Tabel 4.

Umumnya sapi potong yang dipelihara di Kabupaten Pesisir Selatan adalah Sapi Pesisir, Sapi Bali, dan Sapi Simmental. Populasi ternak sapi potong menyebar secara merata di semua kecamatan yang ada di Kabupaten Pesisir Selatan yaitu Kecamatan Koto XI Tarusan, Kecamatan Bayang, Kecamatan IV Jurai, Kecamatan Batang Kapas, Kecamatan Sutera, Kecamatan Lengayang, Kecamatan Ranah Pesisir, Kecamatan Linggo Sari Baganti, Kecamatan Pancung Soal, Kecamatan Basa IV Balai Tapan, dan Kecamatan Lunang Silaut dan Kecamatan yang memiliki populasi terbesar adalah Kecamatan Ranah Pesisir sebanyak 15.890 ekor.

Bila diperhatikan dari segi penggunaan lahan pada wilayah ini, 30.466 Ha merupakan lahan pertanian yang tergolong kedalam lahan sawah, dan 237,871 Ha merupakan lahan pertanian bukan sawah yaitu berupa tegal/ kebun, ladang/huma, perkebunan, hutan rakyat, tambak, kolam dan padang rumput, serta $306.652 \mathrm{Ha}$ merupakan lahan bukan pertanian yang terdiri dari lahan rumah /bangunan dan halaman sekitar, hutan Negara, rawa-rawa dan lainnya. Jika kita perhatikan luas tanah di Kabupaten Pesisir Selatan menurut penggunaannya, komposisinya adalah terdiri dari 5,16\% lahan sawah dan 94,84\% lahan bukan sawah. Luas kawasan hutan mencapai $71,15 \%$ dan $52,82 \%$ diantaranya merupakan hutan lebat. Sedangkan lahan yang dimanfaatkan untuk tanaman perkebunan hanya $13,04 \%$ saja dari luas wilayah.

Jadi dapat diambil kesimpulan bahwa potensi lahan yang ada di kabupaten ini untuk pengembangan sapi potong hanya bisa untuk usaha sapi potong intensif sedangkan untuk pemeliharaan sapi potong system extensive tidak bisa dilakukan hal ini dikarenakan tidak tersedia lahan yang benar-benar untuk pemeliharaan sapi potong, namun untuk pemeliharaan sapi dapat dilakukan pada sawah, lahan perkebunan, hutan negara, hutan rakyat dan tegalan mempunyai potensi untuk pemeliharaan sapi potong. Menurut Soedarmadi et al. (1996) bahwa sumber daya lahan yang potensial sebagai sumber hijauan pakan ternak yang digunakan untuk kebutuhan konversi tersebut adalah lahan baku yang meliputi padang rumput, lahan tegalan, sawah, rawa, perkebunan dan kehutanan.

Tabel 4. Peningkatan Populasi Ternak Sapi Potong di Kabupaten Pesisir Selatan

\begin{tabular}{cccc}
\hline Tahun & $\begin{array}{c}\text { Populasi } \\
\text { (Ekor) }\end{array}$ & $\begin{array}{c}\text { Penambahan } \\
\text { (Ekor) }\end{array}$ & Perkembangan (\%) \\
\hline 2007 & 84.200 & 1.803 & 2,188 \\
2006 & 82.397 & 974 & 1,196 \\
2005 & 81.423 & 486 & 0,600 \\
2004 & 80.937 & 1.737 & 2,193 \\
2003 & 79.200 & - & - \\
\hline
\end{tabular}

Sumber : BPS Kabupaten Pesisir Selatan (2009)

Tabel 5. Populasi Ternak Ruminansia di Kabupaten Pesisir Selatan

\begin{tabular}{ccc}
\hline Jenis Ternak & $\begin{array}{c}\text { Populasi } \\
\text { (Ekor) }\end{array}$ & $\begin{array}{c}\text { Satuan Ternak } \\
(\text { ST) }\end{array}$ \\
\hline Sapi Potong & 84.200 & $84.200,00$ \\
Sapi Perah & 0 & 0 \\
Kerbau & 28.922 & $28.922,00$ \\
Kambing & 26.706 & $3.738,84$ \\
Domba & 0 & 0 \\
\hline Jumlah & 139.828 & $116.860,84$ \\
\hline
\end{tabular}

Sumber : BPS Kabupaten Pesisir Selatan (2009) 


\section{Kondisi Umum Peternak Sapi Potong.}

Keberadaan sumberdaya manusia tidak terlepas dari suatu pengembangan peternakan. Sumberdaya manusia yang berkaitan dengan usaha pengembangan sapi potong di Kabupaten Pesisir Selatan adalah peternak sebanyak 29.270 KK. Peternak sebagai pengelola, merupakan faktor penentu dalam mencapai keberhasilan usaha. Usaha pengembangan peternakan tidak bisa terlepas dari peternak itu sendiri sehingga karakteristik perlu diketahui.

Umur peternak di Kabupaten Pesisir Selatan yang paling muda berumur 20 tahun dan paling tua berumur 61 tahun. Sebesar $58,59 \%$ peternak berada pada kisaran umur 20 -45 tahun. Hal ini menunjukkan bahwa usaha peternakan sapi potong di Kabupaten Pesisir Selatan sudah dilakukan pada usia produktif, hal ini tentunya akan berdampak kepada produktifitas, karena semakin banyak peternak yang berusia lanjut dalam berusaha semakin tidak produktif.

Tingkat pendidikan peternak di Kabupaten Pesisir Selatan sebesar 20,2\% menyelesaikan pendidikan formalnya. Peternak yang tidak tamat Sekolah Dasar/sederajat sebesar $5 \%$ dan peternak yang melanjutkan ke perguruan tinggi sebesar $12,1 \%$. Sedangkan sisanya $62,9 \%$ peternak tidak sampai selesai menamatkan pendidikan formalnya, 35,36\% hanya sampai tingkat SD dan $27,28 \%$ hanya menyelesaikan hingga tingkat SLTP. Hal ini menunjukkan bahwa peternak sapi potong di Kabupaten Pesisir Selatan mempunyai tingkat pendidikan yang rendah sehingga mengakibatkan peternak sukar mengadopsi inovasi teknologi untuk meningkatkan usahanya.

Pengalaman dalam beternak sapi potong di Kabupaten Pesisir Selatan rata-rata besar dari 10 tahun yakni berkisar $44,45 \%$. Adapun yang beternak kisaran 6-10 tahun adalah sebesar $26,27 \%$. Semakin lama peternak menjalankan usahanya maka akan semakin banyak pula pengalaman yang mereka peroleh sehingga dapat dijadikan pedoman dalam menghadapi permasalahan dalam menjalankan usaha ternak sapi potong.

Jumlah tanggungan keluarga peternak berkisar antara $1-3$ orang sebesar $60,61 \%$, se- dangkan kisaran 4-6 orang sebesar 38,39\%, dan hanya $1 \%$ tanggungan keluarga peternak yang berjumlah besar dari 6 orang. Besarnya jumlah anggota keluarga akan meningkatkan tanggung jawab peternak dalam mengelola usahanya karena semakin besar tanggungan keluarga maka biaya hidup keluarga akan semakin besar pula.

Motivasi beternak di Kabupaten Pesisir Selatan menjadikan usaha sapi potong ini sebagai mata pencaharian sampingan adalah $79,80 \%$ hanya sebagian kecil yang menjadikan usaha sapi potong sebagai kebutuhan utama yakni $20,21 \%$. Ini adalah salah satu faktor kelemahan yang yang sangat kuat dalam pengembangan sapi potong di Kabupaten Pesisir Selatan.

Usaha ternak sapi potong di daerah ini pada umumnya dilakukan sebagai usaha sambilan, karena pekerjaan utama mereka adalah petani. Peternak yang menjadikan usaha ternak sapi potong sebagai usaha pokok hanya $20 \%$. Meskipun begitu, pada dasarnya peternak di daerah ini sudah menjalankan usaha ternak sapi potong dalam kurun waktu yang cukup lama. Hal ini dapat dilihat dari tingkat pengalaman peternak dalam beternak yang lebih dari 10 tahun di mana peternak memiliki jumlah ternak sapi potong untuk masingmasing peternak adalah 1-4 ekor dengan lama penggemukan berkisar antara 4-6 bulan .

Jumlah ternak sapi rata-rata 4 ekor untuk masing-masing peternak tersebut, biasanya dalam melakukan pemeliharaan selalu melibatkan semua anggota keluarga. Keterlibatan anggota keluarga juga berbeda-beda dalam usaha pemeliharaan ternak, yang mana $37,3 \%$ yang terlibat itu adalah bapak atau ibu, $55,7 \%$ adalah bapak atau ibu dan anak, kemudian $7 \%$ yang terlibat adalah semua anggota keluarga dalam usaha pemeliharaan ternak sapi potong.

Usaha peternakan sapi potong di daerah ini merupakan usaha keluarga dan yang terlibat dalam usaha ini juga para anggota keluarga, untuk jumlah rata-rata ternak masingmasing peternak tersebut dalam pemeliharaannya masih bisa diselesaikan oleh semua anggota keluarga saja dan berarti belum mem- 
butuhkan tambahan tenaga kerja dari luar, hal ini dapat dilihat dimana sebanyak $93 \%$ peternak mengatakan tidak membutuhkan tambahan tenaga kerja dari luar dan hanya $7 \%$ peternak yang merasakan kekurangan tenaga kerja dan membutuhkan tambahan tenaga kerja dari luar.

Pemeliharaan ternak sapi potong pada dasarnya meliputi berbagai macam kegiatan, seperti memberi makan, menyabit rumput, membersihkan kandang dan memandikan ternak. Berdasarkan jenis pekerjaan untuk pemeliharaan ternak sapi potong juga membutuhkan waktu kerja perhari yang berbeda, dimana untuk memberikan makanan membutuhkan waktu kerja 0,15 jam/ekor/hari, waktu ini sama dengan 0,0187 HOK. Pekerjaan menyabit rumput membutuhkan waktu kerja 0,5 jam /ekor/hari, ini juga sama dengan 0,0625 HOK, untuk membersihkan kandang dan memandikan membutuhkan waktu kerja 0,10 jam/ekor/hari berarti sama dengan 0,0125 HOK.

Berdasarkan jenis pekerjaan maka waktu yang diperlukan untuk memelihara satu ekor ternak per hari adalah 0,75 jam/ekor/hari, angka ini berarti sama dengan 0,0938 HOK. Dari hasil tersebut dapat dilihat bahwa waktu kerja untuk mencari pakan lebih besar dibandingkan dengan waktu kerja yang dibutuhkan untuk kegiatan lainnya, walaupun tidak terlalu besar perbedaannya, hal ini menurut Zainal (1997) disebabkan karena aktifitas yang dilakukan dalam pencarian pakan ternak dilakukan setiap hari.

\section{Employment Elastisity Usaha Peternakan di Kabupaten Pesisir Selatan}

Elastisitas kesempatan kerja di sektor peternakan di Pesisir Selatan ini dapat dihitung dengan membandingkan perubahan struktur dan laju pertumbuhan kesempatan kerja di sektor peternakan dengan perubahan struktur dan laju pertumbuhan ekonomi untuk melihat besarnya elastisitas tersebut kita terlebih dahulu melihat pertumbuhan ekonomi Kabupaten Pesisir Selatan pada Tabel 6. Dari Tabel 6 kita sudah bisa menghitung Employment elastisity sektor peternakan di
Kabupaten Pesisir Selatan yaitu sebesar 0,24 yang diperoleh dari perhitungan rumus sebagai berikut :

$$
\begin{aligned}
& \mathrm{Ei}=\mathrm{RLi} / \mathrm{RYi} \\
& \mathrm{Ei}=3,6 / 15 \cdot 21=0,24
\end{aligned}
$$

Dimana:

$\mathrm{Ei}=$ elastisitas kesempatan kerja sektor $\mathrm{i}$ (peternakan)

Rli = Laju pertumbuhan kesempatan kerja sektor I (peternakan)

Ryi = Laju pertumbuhan nilai tambah sektor I (peternakan)

Apabila laju pertumbuhan ekonomi sektor i (RYi) pertahun diketahui, maka dapat ditentukan besarnya kesempatan kerja sektor I pada tahun $\mathrm{t}$ di masa yang akan datang dengan menggunakan formula sebagai berikut :

$$
\begin{aligned}
\text { Rli } & =\text { Ei } \times \text { Ryi } \\
\text { Rli } & =0,24 \times 15.21 \\
& =3,65
\end{aligned}
$$

Kemudian dengan menggunakan laju partumbuhan kesempatan kerja sektor I (peternakan), maka dapat ditentukan besarnya kesempatan kerja sektor i pada tahun $t$ dimasa yang akan datang dengan asumsi kesempatan kerja sektor i pada tahun 2000 sebagai tahun dasar dengan rumus berikut :

$$
\text { Lit }=\operatorname{Lio}(1+\text { Rli })^{t}
$$

Dimana :

Lit $=$ Kesempatan kerja sektor i pada tahun $\mathrm{t}$

Lio $=$ Kesempatan kerja sektor i pada tahun dasar

Rli = Laju pertumbuhan kesempatan kerja pertahun

Dari pembahasan Tabel 7 dapat diketahui bahwa elastisitas kesempatan kerja sektor peternakan di pesisir selatan sebesar 0,24, artinya apabila PDRB Kabupaten Pesisir Selatan bertambah 1\%, maka akan terjadi penciptaan kesempatan kerja di sektor peternakan sebesar 0,24\%. Dari nilai elastisitas 
yang didapat, kita bisa menghitung laju pertumbuhan kesempatan kerja sektor peternakan dengan menggunakan perkalian nilai elastisitas dengan laju pertumbuhan sektor peternakan atas dasar harga konstan 2000 (PDRB sub sektor peternakan atas dasar harga konstan 2000), didapatkan nilai laju partumbuhan kesempatan kerja sektor peternakan sebesar 3,65. Dari nilai laju pertumbuhan kerja nantinya bisa juga memproyeksikan besarnya kesempatan kerja pada tahun berikutnya dengan asumsi menggunakan laju pertumbuhan nilai sektor peternakan atas dasar harga konstan tahun 2000 dan memakai angka kesempatan kerja sektor peternakan tahun 2000 sebagai kesempatan kerja dasar, hasilnya seperti Tabel 6.

Secara makro, elastis kesempatan kerja digunakan untuk memperkirakan laju pertumbuhan produksi yang diperlukan untuk mengimbangi laju pertumbuhan angkatan kerja yang ada. Begitu pula sebaliknya berapa besar angkatan kerja yang diperlukan untuk mengimbangi laju kenaikan produksi yang ada. Indikator elastis ini sering digunakan untuk menganalisis sifat usaha padat modal dan padat karya.

Peningkatan SDM di lingkungan dunia usaha menuntut keterlibatan pemerintah dan pihak lain yang terkait. Pengembangan tenaga sangat penting kita lakukan dan banyak manfaatnya dan salah satu yang bisa dilakukan untuk usaha peternakan adalah progam pelatihan dan manejerial dalam pengembangan, selain itu memadukan training dan pengembangan modal bagi peternak.

Latihan dan training ini dimaksudkan untuk memperbaiki penguasaan di berbagai teknik serta keterampilan pelaksanaan kerja tertentu dalam kurun waktu yang relatif singkat. Program pengembangan dan latihan akan meningkatkan produktivitas tenaga kerja. Untuk jangka panjang perubahan permintaan tenaga kerja dapat terjadi dalam bentuk loncatan atau shift, di mana perubahan ini diakibatkan oleh adanya perubahan dalam penggunaan teknologi dan metode produksi. Sedangkan untuk meningkatkan daya serap terhadap permintaan tenaga kerja adalah dengan meningkatkan tingkat upah dan pendapatan masyarakat, sehingga akan meningkatkan permintaan konsumsi oleh masyarakat. Perubahan permintaan konsumsi ini akan mempengaruhi permintaan tenaga kerja, dengan naiknya tingkat pendapatan masyarakat berarti akan meningkatkan permintaan tenaga kerja.

Berdasarkan hasil survey tentang penyerapan tenaga kerja untuk pemeliharaan ternak dapat diketahui bahwa rata-rata peternak memiliki ternak sapi sebanyak 4 ekor dengan curahan waktu untuk pemeliharaannya sebanyak 3 jam dalam satu hari. Ini berarti satu ekor ternak hanya membutuhkan waktu 0,75

Tabel 6. Perkembangan PDRB atas Harga Konstan Tahun 2000 dan Kerja Sub sektor Peternakan di Kabupaten Pesisir Selatan

\begin{tabular}{llccc}
\hline No & \multicolumn{1}{c}{ Uraian } & Tahun 2007 & Tahun 2008 & Laju pertumbuhan \\
\hline 1 & PDRB Kab.Pesisir Selatan & $3.082 .919,44$ & $3.580 .153,38$ & 16,13 \\
2 & PDRB sektor Peternakan & $104.172,27$ & $120.015,11$ & 15,21 \\
3 & Kesempatan kerja peternakan & 29.270 & 30.323 & 3,6 \\
\hline
\end{tabular}

Sumber : Pesisir Selatan dalam angka tahun 2009

Tabel 7. Perkiraan Kesempatan Kerja Di Sub Sektor Peternakan Pada Tahun 2009 - 2011 di Pesisir Selatan

\begin{tabular}{ccccc}
\hline Tahun & Lio (orang) & Rli & $(1+\mathrm{Rli})^{\mathrm{t}}$ & Lit (orang) \\
\hline 2009 & 26.789 & 3,65 & 4,65 & $124.568,85$ \\
2010 & 26.789 & 3,65 & 21,62 & $579.245,15$ \\
2011 & 26.789 & 3,65 & 100.533 & $2.693 .178,54$ \\
\hline
\end{tabular}

Sumber : data diolah 2010 
jam/ekor/hari untuk pemeliharaannyan yang meliputi kegiatan menyabit rumput, membersihkan kandang, memandikan sapi dan memberi makan. Dari sini dapat kita hitung seorang pekerja yang biasanya bekerja 8 jam dalam satu hari bila jam kerjanya di alokasikan untuk pemeliharaan sapi, maka pekerja itu bisa memelihara 10 ekor sapi dalam satu hari kerja. Jadi dari total populasi yang ada di Pesisir selatan ini sebesar 116.860 ST bisa menyerap tenaga kerja lebih kurang sebanyak 11.686 orang.

\section{KESIMPULAN DAN SARAN}

\section{Kesimpulan}

Sumber daya manusia khususnya peternak di daerah ini belum memadai untuk mengembangkan usahanya ke arah yang lebih baik, hal ini terlihat dari pendidikan dan curahan waktu kerja untuk usaha sapi potong di mana $62,9 \%$ peternak tidak menamatkan pendidikan formalnya serta pengetahuan secara teknis yang masih rendah walaupun sudah mempunyai pengalaman beternak ratarata di atas 10 tahun. Waktu yang diperlukan untuk memelihara satu ekor ternak perhari adalah $0,75 \mathrm{jam} / \mathrm{ekor} / \mathrm{hari}$ atau sama dengan 0,0938 HOK.

1. Elastisitas kesempatan kerja di sektor peternakan di Kabupaten Pesisir Selatan dapat dihitung dengan membandingkan perubahan struktur dan laju pertumbuhan kesempatan kerja disektor peternakan dengan perubahan struktur dan laju pertumbuhan ekonomi, pada penelitian ini didapat angka elastisitas tenaga kerja sebesar 0,24. Artinya apabila terjadi kenaikan PDRB $1 \%$ maka akan mempengaruhi penyerapan tenaga kerja sebesar $24 \%$.

\section{Saran}

1. Keberadaan berbagai potensi tenaga kerja untuk pengembangan ternak sapi potong dapat dijadikan bahan pertimbangan dalam upaya pengembangan peternakan lebih lanjut. Berdasarkan hasil penelitian ini ternyata untuk pengembangan sapi potong di Kabupaten ini perlu perencanaan yang matang dari pemda setempat agar mengusahakan pengembangan peternakan melalui peningkatan pengembangan sumber daya manusia. Baik dari segi pendidikan dan keterampilan dalam berusaha ternak sapi potong.

2. Sub sektor peternakan merupakan peluang untuk menciptakan lapangan pekerjaan bagi masyarakat di daerah ini, oleh karena itu penanganan terhadap sektor hulu, hilir dan sistem pendukung harus lebih dioptimalkan lagi keberadaannya.

\section{DAFTAR PUSTAKA}

Badan Pusat Statistik. 2007 dan 2009. Sumatera Barat Dalam Angka. Kerjasama Bappeda TK I dengan BPS Propinsi Sumatera Barat

Dirjen Peternakan. 2003. Usaha Peternakan, Perencanaan Usaha Analisa dan Pengelolaan. Jakarta

Dinas Peternakan. 2006. Data Base Peternakan Propinsi Sumatera Barat Tahun 1996 - 2005. Pemerintah Propinsi Sumatera Barat

Dinas Peternakan Sumbar, 2007. Revitalitas Potensi Lokal untuk Mewujudkan Swasembada Daging 2010 dalam Kerangka Pembangunan Peternakan yang Berkelanjutan dan Peningkatan Kesejahteraan Masyrakat. Seminar Nasional Perternakan 11-12 September 2006 Padang.

Dinas Peternakan Kabupaten Pesisir Selatan, 2009. Dokumen RPJMD.

Dwiyanto. 2002. Pemanfaatan Sumberdaya Lokal dan Inovasi Teknologi dalam mendukung Usaha Agribisnis yang Berdaya Saing, Berkelanjutan dan Berkerakyatan, Wartazoa 12 (1) : $1-8$ 
Natasasmita, A dan Koeswardono, M. 1979. Beternak Sapi Daging. Fakultas Peternakan Institut Pertanian Bogor, Bogor.

Salikin,K.A. 2003. Sistem Pertanian Berkelanjutan. Kanisius. Yogyakarta
Singarimbun dan Effendi. 1989. Metode Penelitian dan Survei. PT. Pustaka LP3ES Indonesia, Jakarta

Suryana. 2009. Pengembangan Usaha Ternak Sapi Potong Berorientasi Agribisnis dengan Pola Kemitraan. Jurnal Litbang Pertanian, 28(1), hal. 29-37. 